甲状腺髄様癌術後肝転移に対し肝動脈化学塞栓療法が有効であった 1 例

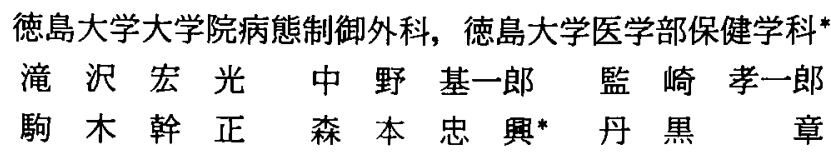

甲状腺髄様癌術後の肝転移に対し肝動脈化学塞栓療法を施行し, 以後 2 年間腫瘍マ一カーの上昇なく病状コントロールできている症例を経験したので報告する。患者は女性. 14歳時に甲状腺髄様癌（pT2bN1bM0）にて甲状腺全摘術と D3a 郭清を施行した．17歳 の頃から CEA, カルシトニン值が徐々に上昇したため種々の画像診断を行ったが再発, 転移巣は明らかでなかった。 22歳時の造影 CT で肝内に造影早期相で濃染する $1.5 \mathrm{~cm}$ 大 までの結節影を多数認め, 腫啺マーカーは CEA $852.9 \mathrm{ng} / \mathrm{ml}$, カルシトニン $12,100 \mathrm{pg} / \mathrm{ml}$ まで上昇していた。これらの病変に対し動脈化学塞栓療法を計 3 回施行した。. 以後 2 年 経過するが肝の結節影に增大傾向は認めず, 腫瘍マーカーは CEA $577.5 \mathrm{ng} / \mathrm{ml}$, カルシ トニン $6.400 \mathrm{pg} / \mathrm{ml}$ とピーク時より低下したレべルで横ばいとなっており健在である.

索引用語：甲状腺髄样癌, 転移性肝癌, 肝動脈化学塞栓療法

\section{緒 言}

甲状腺髄样癌は稀な疾患であり，手術以外の有効な 治療法は確立していない。甲状腺䯣様癌術後の肝転移 に対し肝動脈化学塞栓療法を施行し，以後 2 年間腫煌 マーカーの上昇なく病状コントロールできている症例 を経験したので報告する。

\section{症 例}

患者：女性.

初診時主訴：前頸部腫瘤。

家族歴：父，兄に甲状腺腫の既往なし。母は既に心 疾患で死亡しており詳細不明。

既往歴：特記事項なし。

経過：14歳時に前頸部腫瘤に気付き近医を受診し た. 甲状腺腫瘍を指摘され精查加療目的で当科に紹介 された。甲状腺左下に $3 \mathrm{~cm}$ 大の表面平滑で可動性良 好な弾性硬の腫瘤を触知した。頸部リンパ節の腫大は 認めなかった。超音波検査では同部に長径 $3.7 \mathrm{~cm}$ の内 部不均一で粗大な石灰化を伴う境界明瞭な腫瘤が描出 された（図 1 ）。また右葉に $3 \mathrm{~mm}$ 大の腫瘤も認めた。 主病巣から行った穿刺吸引細胞診では核の大小不同が

2005年 1 月 24 日受付 2005 年 4 月 20 日採用 〈所属施設住所〉

₹770-8503 徳島市蔵本町 3-18-15
目立つ短紡鏵型細胞からなる細胞集塊が認められ, 髄 様癌として矛盾せず class Vの結果であった，血液検 査では CEA 193ng $/ \mathrm{ml}$ ，カルシトニン $13,200 \mathrm{pg} / \mathrm{ml}$ と 著明に上昇していた，尿中カテコラミン值の軽度上昇 を認めたため多発性内分泌線腺症 2 型の可能性も考之 られたが，腹部 CT では副腎に異常を認めなかった。 以上より甲状腺艏様癌の術前䛦断にて手術を施行し た。術中迅速診断にて右葉の腫煌も悪性所見が認めら れたため甲状腺全摘術と D3a 郭清を施行した。組織学 的に両葉の腫貆は共に紡錘形細胞の充実性びまん性增 殖を認め,アミロイドを含む硝子用の間質を伴ってお り葡様癌として矛盾しない像であった(図 2)。リンパ 節転移は左 $\mathrm{III}(+), \mathrm{V}(+), \mathrm{VI}(+)$, 右 $\mathrm{III}(+) て ゙ \mathrm{pT} 2$ bN1bM0であった。後に行われたDNA 検査でRET 遺伝子 exon 11 codon 634 に変異を認め, 遺伝性髄様 癌と診断された。術後腫瘍マーカーは CEA 14.2ng/ $\mathrm{ml}$, カルシトニン $73.5 \mathrm{pg} / \mathrm{ml}$ まで低下したが正常化に は至らなかった。術後每年定期的に形胸腹部造影 CT を行っていたが異常は指摘されなかった，17歳の頃か ら CEA, カルシトニン值が徐々に上昇したため, CT に加え骨シンチ，腹部超音波検査などの画像診断を行 ったが再発, 転移巣は明らかでなかった．22墄時の造 影 CT で肝内に造影早期相で濃染する $1.5 \mathrm{~cm}$ 大まで の結節影を多数認めた(図 3 )。この時点の腫晹マーカ 


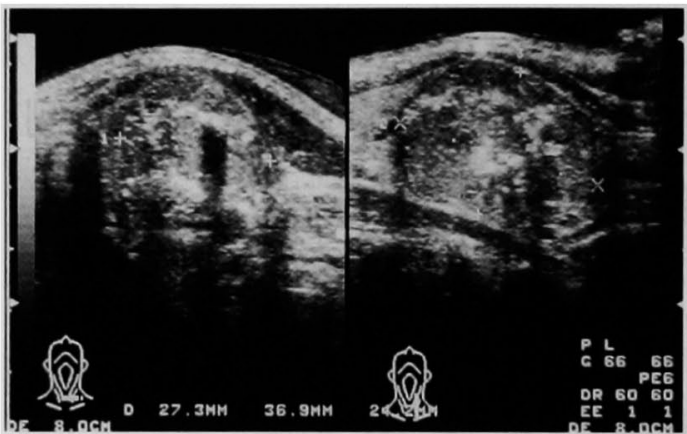

図 1 頕部超音波所見：長径 $3.7 \mathrm{~cm}$ 大の内部不均一で 粗大な石灰化を伴う境界明瞙な腫瘤が描出された。

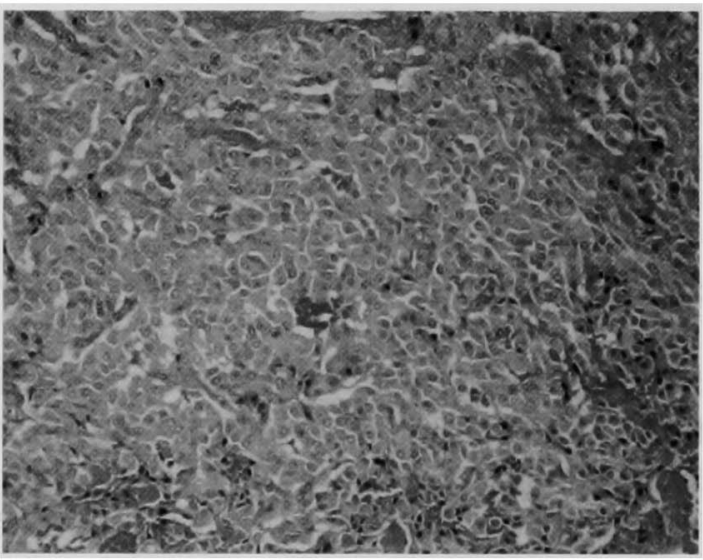

図 2 病理組織所見：紡鍾形細胞の充実性びまん性増殖 を認めた（H-E 染色，×200）。

ーは CEA $852.9 \mathrm{ng} / \mathrm{ml}$ ，カルシトニン $12,100 \mathrm{pg} / \mathrm{ml}$ ま て上昇していた，MIBI シンチでは肝に一致した集積 を諗めた。選択的肝動脈造影にて肝の両葉にわたり多 数の造影早期に濃染する綿花様の腫瘤影を楒めた（図 4).甲状腺髄様癌の肝転移と診断し 3 力月の間に動脈 化学塞栓療法を計 3 回施行した. 1 回目は, 塩酸エピ ルビシンと degradable starch microspheres (DSM) を使用した，その後の造影 CTで腫瘍に変化がなかつ たことから， $2 ， 3$ 回目は薬㶡をスマンクス，リピオ ドール,マイトマイシン, DSM に変更し動脈化学塞栓 療法を施行した. 以後外来通院で経過観察中てあるが, 3 回目の動脈化学塞栓療法後 2 年経過した現在, CT にて肝の結節影の数，大きさ共に変化は認めていない (図 5 )。また，腫瘍マーカーは CEA $577.5 \mathrm{ng} / \mathrm{ml}$ ，力 ルシトニン $6,400 \mathrm{pg} / \mathrm{ml}$ とピーク時より低下したレべ ルで横ばいとなっており健在である（図6）。
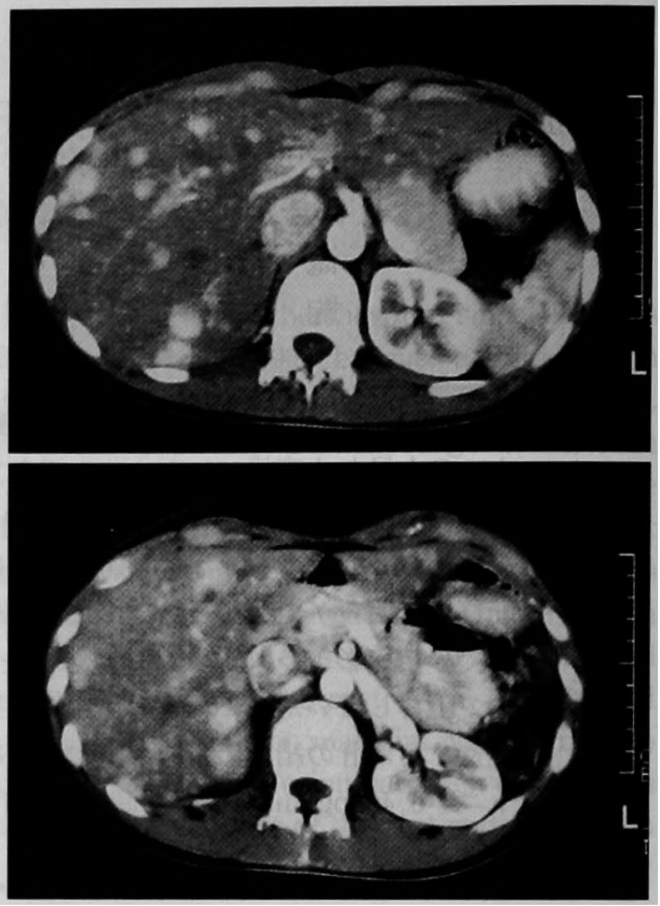

図 3 肝転移発見時腹部造影 CT 所見：肝内に 1.5 $\mathrm{cm}$ 大までの造影早期に濃染する腫瘤を多数認め た.

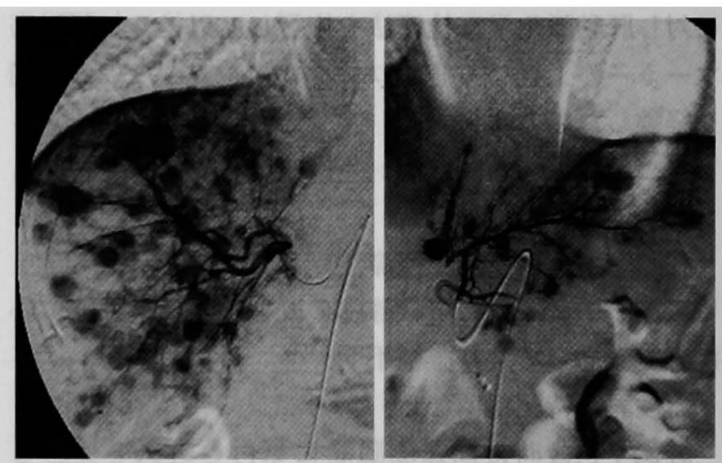

図4 腹部動脈造影所見：選択的肝動脈造影にて肝の両 葉にわたり多数の造影早期に濃染する綿花様の腫瘤影 を認めた。

考察

甲状腺悪性腫瘍中の㵦樣癌は $1.3 \%$ を占めるに過ぎ ず稀な組織型であり"，うち遗伝性髄様癌の頻度は39 \%である2!。近年，末梢血 DNA 検査が可能となり， RET 遺伝子の変異を証明することで遺伝性䯣様癌の 診断が容易になった．䯣様癌の治療方針については単 発性の散発性髄様癌に対しては葉切除で十分との意見 


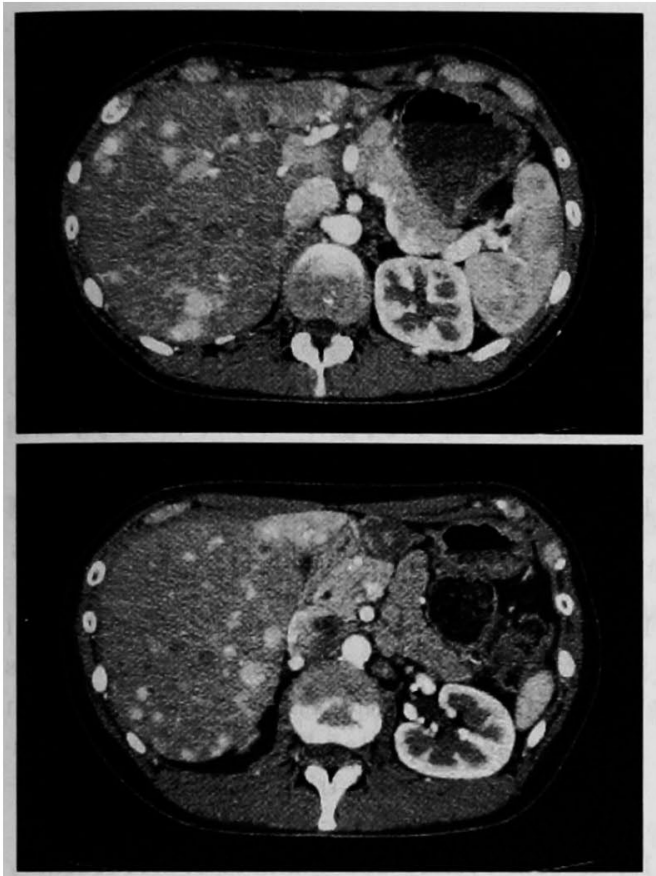

図 5 治癔 2 年啳の腹部造影 CT 所見 : 肝の腫瘤影 には大きな変化を認めない。

がある一方, 遺伝性髄様癌には両葉発生が $84.1 \%$ と多 く全摘術が必要であると考えられている3)。本症例に おいて患者の母は既に死亡していたため詳細は不明て あるが, 父, 兄には甲状腺腫, 高血圧などは認めず RET 遗层子の変異も認めなかった。術前に遺伝子検查は行 われていなかったが, 病変が両葉に認められたことか ら全摘術となり，後に遺伝性髄様癌と診断された。

甲状腺髄样癌の 10 年生存率は $77.8 \%$ と報告されてち り"，再発様式としては局所再発が多く，遠隔転移は 肝, 肺, 骨の順に頻度が高い3). 髄样癌の腫場マーカー はCEA とカルシトニンであり，病勢をよく反映する 指標である ${ }^{5) 6}$. 本症例では術後 3 年経過する頃より $\mathrm{CEA}$ とカルシトニンの上昇が目立ち始めたため種々 の画像診断を行ったが再発，転移巣が発見できず，結 果的に肝転移を発見するまでに数年が経過した．同様 に鲢樣癌症例においては腫瘍マーカーの上昇と検出さ れる病巣が相応しないことがある781.この原因の 1 つ に再発リンパ節と肝転移巣の検出には従来の CT を含 めた画像診断では不十分との意見がある゙1.この報告 では髄樣癌の肝転移の検出には動脈造影が有効であ り，感度は $89 \%$ であったとある。本症例は造影 CT が 肝転移発見の契機となった。CT装置の進歩により時

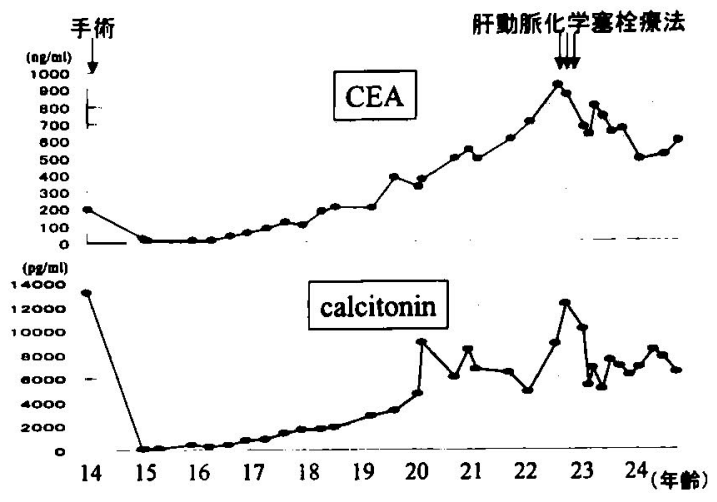

図 6 治療経過と腫痬マーカ一の推移：CEA，カルシト ニン共に肝動脈化学塞栓療法後は上昇していない.

間分解能が向上し，多相性のダイナミック CTも可能 となった，その反面，対象臓器と造影剤の血行動態を 十分理解し検查を行わないと不十分な検査となる可能 性もある゙!. 本症例についても，造影 CTで毎年頸部か ら上腹部までの再発, 転移の検索を行っていたが, 肝 臓を対象とした造影と撮影のタイミングを設定してい なかったことは反省すべき点であり，放射線科医との 連絡が重要と考えられる。

肝細胞癌と異なり，一般に転移性肝癌は乏血性であ るため，リザーバーを用いた動注化学療法の有効性が 報告されるとともに肝動脈塞栓術は行われなくなって きた ${ }^{(0)}$.しかし，内分泌癌は血流が豊富で，その肝転移

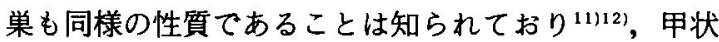
腺艏様癌も同様である考えられる ${ }^{8 !}$. 従って肝動脈塞 栓療法の適応について検討の余地はあるであろう. 本 症例のように多発するすべての転移巣に十分な阻血効 果をもたらすのは不可能である。このため, 徐放性抗 癌剛の効果を期待しマイトマイシン, 塩酸エピルビシ ンを用いた DSM 併用肝動脈化学塞栓療法とした。肝 細胞癌に対する肝動脈化学塞栓療法の効果は既に報告 され ${ }^{13)}$, 最近の無作為化比較試験では生存率の延長に 寄与することも認められた ${ }^{14}$. 甲状腺髄样癌の肝転移 巣に肝動脈化学塞栓療法の効果が認められた症例も報 告されている(15)16). 本症例でも治療後 2 年間腫瘍マー カーの増加なく経過していることから一定の効果が得 られたと考えられる。

\section{結 語}

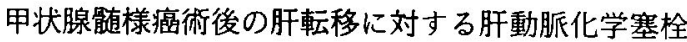
療法は治療法のオプションとなり得ると考えられる. 


\section{文献}

1）甲状腺甥性腫㻛登録委員会：甲状腺悪性腫場登録 集計 (1977 2001)．第36回甲状腺外科研究会抄録 华, 2003

2）高見 博, 奄山香織, 細田康弘: MEN2型の集 計：第28回甲状腺外科検討会アンケート集計よ り.内分泌外科 $13: 1-8,1996$

3）宮澤幸正, 坂田治人，川島太一他：散発性甲状腺 骮様癌に対する診断と治療 遗伀性との対比. 臨 外 $59: 413-417,2004$

4）阿部力哉：甲状腺癌の 10 年生存率. 第29回甲状腺 外科検討会当番世話人報告集, 1996

5) Tisell LE, Dilley WG, Wells SA Jr : Progression of postoperative residual medullary thyroid carcinoma as monitored by plasma calcitonin levels. Surgery $119: 34-39,1996$

6) Mendelsohn G, Wells SA Jr, Baylin SB: Rela. tionship of tissue carcinoembryonic antigen and calcitonin to tumor virulence in medullary thyroid carcinoma. An immunohistochemical study in early, localized, and virulent disseminated stages of disease. Cancer $54: 657-$ 662,1984

7) Busnardo B, Girelli ME, Simioni $N$, et al: Nonparallel patterns of calcitonin and carcinoembryonic antigen levels in the follow-up of medullary thyroid carcinoma. Cancer 53 : 278-285, 1984

8) Esik O, Szavcsur P, Szakall S Jr, et al : Angiography effectively supports the diagnosis of hepatic metastases in medullary thyroid carcinoma. Cancer $91: 2084-2095,2001$

9）伊藤加奈子, 山下康行：マルチスライスCTにお ける造影剂の有効な使用方法.日本医放会誌 $62: 675-681,2002$

10)棚田 稔, 久保義郎, 高嶋成光：癌肝転移に対す る肝動脈塞拴療法. 臨外 $58: 786-788,2003$

11）岡本英三, 山中若樹, 藤元治郎：転移性肝癌の診 断. 臨外 $45: 679-685,1990$

12）中村健一，金澤旭宣，尾崎信弘他：腸間膜動脈の 外膜肥厚を伴った小腸カルチノイドの1例. 日消 外会誌 $37: 702-705,2004$

13）阪口浩, 打田日出夫, 田中利洋他：動脈化学塞 栓療法(TAE/TACE). 日臨 59(增) : 521-527, 2001

14) Llovet JM, Real MI, Montana $X$, et al : Arterial embolisation or chemoembolisation versus symptomatic treatment in patients with unresectable hepatocellular carcinoma : a randomised controlled trial. Lancet $359: 1734-$ 1739, 2002

15) Isozaki $T$, Kiba $T$, Numata $K$, et al : Medullary thyroid carcinoma with multiple hepatic metas. tases:treatment with transcatheter arterial embolization and percutaneous ethanol injection. Intern Med 38:17-21, 1999

16）青柳和彦，高見 博，尾崎修武他：25年間経過観 察した多発性内分泌腺腫症 (MEN) 2B 型の 1 例。 日臨外会誌 $60: 364-370,1999$

\title{
A CASE OF POSTOPERATIVE LIVER METASTASIS FROM MEDULLARY CARCINOMA OF THYROID TREATED WITH CHEMOEMBOLIZATION
}

\author{
Hiromitsu TAKIZAWA, Kiichiro NAKANO, Koichiro KENZAKI, \\ Kansei KOMAKI, Tadaoki MORIMOTO* and Akira TANGOKU \\ Department of Oncological and Regenerative Surgery, University of Tokushima, School of Medicine \\ -University of Tokushima, School of Health Science
}

We report a case of postoperative liver metastasis from medullary carcinoma of thyroid treated with chemoembolization which resulted in stable values of tumor markers for 2 yeas after the treatment.

The female patient underwent total thyroidectomy and lymphadenectomy (D3a) for medullary carcinoma of thyroid (pT2bN1bM0) of the age of 14 . The values of serum CEA and calcitonin gradually increased at the age of 17 , but various imaging examinations showed no recurrence or metastatic lesions. Eight years after the operation when she was 22 , enhanced computed tomographic scan showed multiple metastatic lesions with the diameter of less than $1.5 \mathrm{~cm}$, which were enhanced in the early phase, of the liver. The value of serum CEA was $852.9 \mathrm{ng} / \mathrm{ml}$, and calcitonin was $12100 \mathrm{pg} / \mathrm{ml}$. We performed chemoembolization 3 times for these lesions. Though 2 years have elapsed afterward, no changes in the size or shape of the hepatic masses have been observed and the values of serum CEA and calcitonin remains relatively low (CEA : $577.5 \mathrm{ng} / \mathrm{ml}$ and calcitonin $: 6400 \mathrm{pg} / \mathrm{ml}$ ). 